Article

\title{
Non-Chemical Control of Annual Bluegrass (Poa annua) in Bermudagrass (Cynodon spp.) via Fraise Mowing: Efficacy and Barriers to Adoption
}

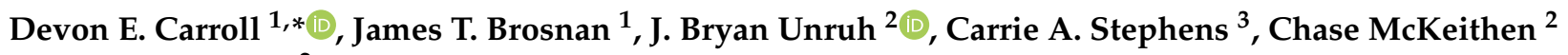 \\ and Pablo A. Boeri ${ }^{2}$ \\ 1 Department of Plant Sciences, The University of Tennessee, Knoxville, TN 37996, USA; jbrosnan@utk.edu \\ 2 West Florida Research and Education Center, The University of Florida, Jay, FL 32565, USA; \\ jbu@ufl.edu (J.B.U.); chasemac@ufl.edu (C.M.); pablo.boeri@ufl.edu (P.A.B.) \\ 3 Department of Agricultural Leadership, Education and Communications, The University of Tennessee, \\ Knoxville, TN 37996, USA; cfritz@utk.edu \\ * Correspondence: dcarro17@vols.utk.edu; Tel.: +570-903-9343
}

check for updates

Citation: Carroll, D.E.; Brosnan, J.T.; Unruh, J.B.; Stephens, C.A.; McKeithen, C.; Boeri, P.A. Non-Chemical Control of Annual Bluegrass (Poa annua) in Bermudagrass (Cynodon spp.) via Fraise Mowing: Efficacy and Barriers to Adoption. Sustainability 2021, 13, 8124. https://doi.org/10.3390/ su13158124

Academic Editors: David Ervin, Sonia Graham, David R. Shaw and George Frisvold

Received: 2 June 2021

Accepted: 17 July 2021

Published: 21 July 2021

Publisher's Note: MDPI stays neutral with regard to jurisdictional claims in published maps and institutional affiliations.

Copyright: (c) 2021 by the authors. Licensee MDPI, Basel, Switzerland. This article is an open access article distributed under the terms and conditions of the Creative Commons Attribution (CC BY) license (https:// creativecommons.org/licenses/by/ $4.0 /)$.

\begin{abstract}
Fraise mowing is a maintenance practice that may serve as a non-chemical means of controlling the problematic weed annual bluegrass (Poa annua L.) in bermudagrass (Cynodon spp.) given reports of efficacy on other turfgrass species. However, an understanding of practitioner decision-making in implementing fraise mowing as a weed-control measure remains unknown. A field study was conducted in Knoxville, TN and repeated in space in Jay, FL during summer 2019 to assess bermudagrass regrowth and subsequent annual bluegrass control, following fraise mowing at depths of 1.5 and $3.0 \mathrm{~cm}$ compared to a non-treated check $(0 \mathrm{~cm})$. Bermudagrass recovered more quickly at the $1.5 \mathrm{~cm}$ depth than the $3.0 \mathrm{~cm}$ depth and was the swiftest in Florida. Fraise mowing at either depth resulted in a $41-97 \%$ reduction in annual bluegrass populations. A qualitative study was conducted in spring 2021, which engaged eight turfgrass managers from Tennessee and Florida via individual interviews in order to understand barriers and challenges to fraise mowing application. Turfgrass managers had positive views of fraise mowing but described challenges in implementation for weed control including cost, labor, area closure, and debris removal.
\end{abstract}

Keywords: turfgrass; herbicide resistance; annual bluegrass; fraise mow; non-chemical control

\section{Introduction}

Covering an estimated $163,800 \mathrm{~km}^{2}$ in the United States, turfgrass is the fifth largest crop in acreage, following barley (Hordeum vulgare L.), corn (Zea mays L.), soybean (Glycine max L. Merr.), and wheat (Triticum spp. L.) [1,2]. Management of such an expansive crop has resulted in an estimated industry value of over $\$ 80$ billion annually and the support of approximately 800,000 jobs [3,4]. Unlike other crops, turfgrass is not grown for optimized yield related to human or animal consumption [5], although greenspaces of maintained turfgrass have great environmental, societal, and economic benefits [6-10].

Managed turfgrass does require regular inputs of mowing, fertilization, irrigation, and pesticide application [5,11], which contribute to carbon emissions and can have adverse environmental effects. However, a unique benefit of turfgrass compared to other crops with similar environmental and societal impacts is the provision of society with greenspace to enhance physical, social, and mental well-being [6].

These benefits of turfgrass may be negatively affected by weed populations. Weeds can introduce unwanted pests, cause allergies, and disrupt landscape aesthetics, particularly during stages of flowering and seedhead production [12-14]. In some situations, the break in turfgrass uniformity caused by weeds can inhibit functionality of the space. For example, on athletic fields, an uneven or compacted playing surface due to weeds can be a player 
safety concern [15]. On golf courses, weeds may impact playability by affecting ball roll on putting greens [16].

Annual bluegrass (Poa annua L.; ABG) is reportedly the most troublesome weed of turfgrass [17]. The light green color, bunch-type growth habit, and prolific seed production of ABG reduces the visual quality of turfgrass swards. Additionally, the species' susceptibility to disease $[18,19]$ and temperature extremes [20] can leave voids in established stands of turfgrass. Because physical or mechanical weed control is limited in turfgrass, ABG is often controlled chemically [11]. However, efficacy has recently declined as herbicide resistance has become more widespread in ABG [21].

In turfgrass, ABG has evolved resistance to herbicidal inhibitors of acetyl-CoA carboxylase [22], acetolactate synthase [23,24], microtubule assembly [25], photosystem II [26], enolpyruvylshikimate-3-phosphate synthase [27], and cellulose biosynthesis [28] via a diversity of mechanisms. Additionally, cases of cross resistance ranging from two to five sites of action have been reported [29]. A recent survey of ABG populations on 90 golf courses in Tennessee, representing 30\% of golf courses in the state, identified $64 \%$ of ABG as resistant to glyphosate (enolpyruvylshikimate-3-phosphate synthase inhibition), $21 \%$ resistant to foramsulfuron (acetolactate synthase inhibition), 58\% resistant to prodiamine (microtubule assembly inhibition), and $97 \%$ resistant to simazine (photosystem II inhibition) [30].

The increasing prevalence of herbicide resistant ABG makes integrated weed management focused on non-chemical strategies essential. Non-chemical weed control strategies also reduce pesticide inputs into the environment, providing a more sustainable weed management approach. Soil seed bank management is a non-chemical weed control strategy implemented to limit spread of herbicide resistant weeds [31]. This approach may be particularly effective when managing weeds such as ABG that produce high volumes of seed. The soil seed bank has been reported to contain upwards of 100,000 ABG seeds $\mathrm{m}^{-2}$ in regions where cool season turfgrass is managed [32-34] and 25,000 ABG seeds $\mathrm{m}^{-2}$ in regions where warm season turfgrass predominates [21].

In turfgrass, fraise mowing can be used as a method of seed bank elimination. Fraise mowing is a cultivation practice that physically removes large quantities of a turfgrass sward (i.e., verdure, thatch, organic matter, soil) (Figure 1). Therefore, fraise mowing is effective during renovation [35], to aid in control of soilborne pathogens [36], to improve herbicidal control of bermudagrass (Cynodon spp.) by removing growing points [37], and as both a preplant and removal technique for overseeded perennial ryegrass (Lolium perenne L.) $[38,39]$. Additionally, the physical removal of upper soil layers includes weed seeds, thus reducing weed populations without use of herbicides. Brosnan et al. [21] found that a single fraise mowing event in June at a depth of $2.5 \mathrm{~cm}$ in zoysiagrass (Zoysia japonica Steud., cv. 'Meyer') resulted in a 24\% ABG reduction. Similarly, Baker et al. [40] observed nearly $100 \%$ control of ABG in a stand of perennial ryegrass following a June fraise mowing event at a depth of $1.8 \mathrm{~cm}$.

Although fraise mowing can be an effective tool for controlling ABG, the aggressive removal of turfgrass leaf tissue can render fraise-mown spaces unusable during the regrowth period. Therefore, timing fraise mowing to facilitate swift turfgrass regrowth is essential to turfgrass quality and weed management as stands lacking density will be susceptible to encroachment of weeds. Turfgrasses possessing both stoloniferous and rhizomatous growth habits such as bermudagrass (Cynodon spp.) are likely to recover from fraise mowing more quickly than species with only stoloniferous or bunch-type growth when fraise mowing is applied during periods of optimal temperature. McCauley et al. [41] found that 'Tifway' and 'Patriot' hybrid bermudagrass (Cynodon dactylon (L.) Pers. $\times$ Cynodon transvaalensis Burtt Davy) required just four to six weeks to fully recover following fraise mowing at 0.6, 1.3 , and $1.9 \mathrm{~cm}$ depths in May and June in North Carolina. Despite the swift regrowth of bermudagrass following fraise mowing and the species comprising the largest acreage of any turfgrass species on golf courses in the United States [42], the efficacy of fraise mowing as a weed control strategy in bermudagrass has yet to be explored. 


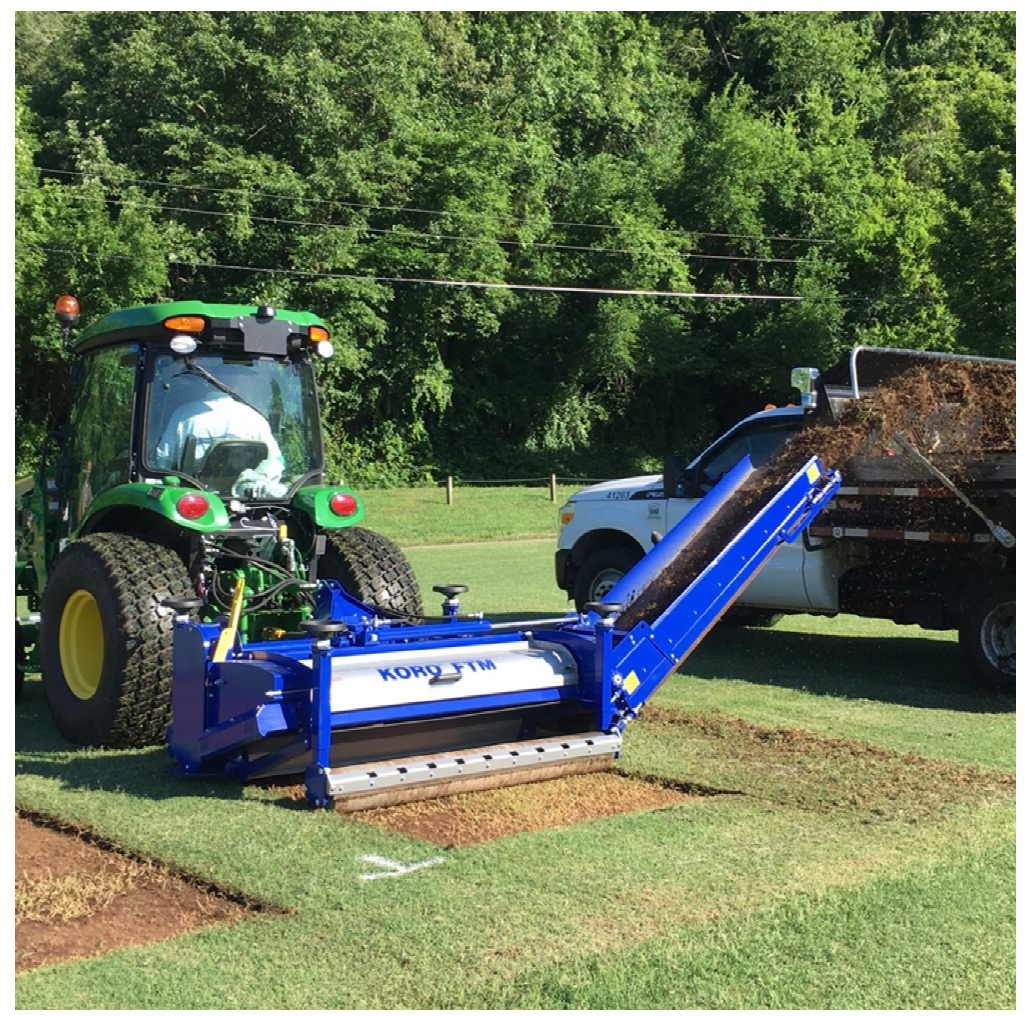

Figure 1. Fraise mowing bermudagrass (Cynodon spp.) with a Koro Field Top Maker affixed to the power take-off assembly of a tractor in Knoxville, TN during June 2019.

Additionally, research has failed to explore barriers affecting adoption of fraise mowing as a weed control strategy. Turfgrass scientists speculate challenges to fraise mowing include cost and labor inputs, space closure following fraise mowing, and debris removal. For example, Brosnan et al. [21] analyzed debris produced by fraise mowing 2.5 ha at a $2.5 \mathrm{~cm}$ depth and found generated debris had a volume of approximately $586 \mathrm{~m}^{3}$, enough to fill about a quarter of an Olympic-sized swimming pool, with a weight of over $9000 \mathrm{~kg}$. Is removing this debris problematic for turfgrass managers?

While turfgrass researchers have inferred factors such as the disruption to turfgrass surfaces and labor costs may influence managers' decisions to fraise mow, these challenges to implementation are only perceived. Turfgrass research generally focuses on quantitative results and lacks the evaluation of factors influencing practitioners' abilities and decisions to implement research findings. Discovering and addressing the influence of economics and social behaviors on practitioner decision-making could facilitate increased implementation of fraise mowing, thus reducing pesticide inputs and mitigating herbicide resistance in ABG.

Based on the lack of research assessing ABG control via fraise mowing in bermudagrass and a poor understanding of factors affecting turfgrass managers' decisions to fraise mow, the objectives of this study were to (1) evaluate bermudagrass regrowth following fraise mowing, (2) assess the efficacy of fraise mowing as a non-chemical control of ABG in bermudagrass, and (3) determine challenges to the adoption of fraise mowing as a weed control strategy.

\section{Materials and Methods}

2.1. Field Assessment of Fraise Mowing Efficacy

2.1.1. Experimental Sites

A field experiment was initiated in mid-June of 2019 in Knoxville, TN and repeated in space in Jay, FL. Both experimental sites are located in the southeastern United States and are of a subtropical climate (Figure 2). 


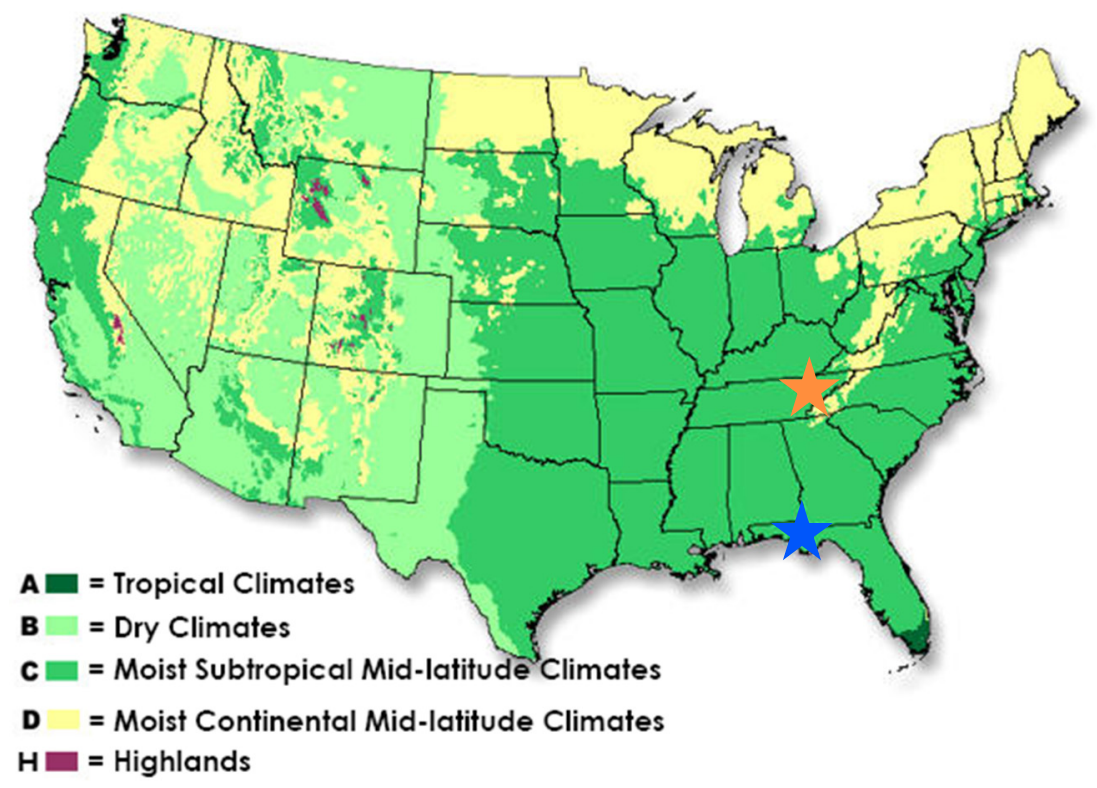

Figure 2. Map of the major climatic zones of the United States. Experimental site locations are both in the subtropical region of the southeastern U.S. (Knoxville, Tennessee = orange star; Jay, Florida = blue star). Map obtained online through the Public Broadcast Service's Learning Media Center. Available: https:/ / tnlearn.pbslearningmedia.org/resource/buac17-35-sci-ess-usclimatezones/ major-us-climate-zones/. Last accessed on 27 April 2021.

In Tennessee, the experimental site was located at Holston River Park (35.974810, -83.862190 ) atop a $100 \%$ Shady-Whitwell complex soil. The study area was comprised of common bermudagrass (Cynodon dactylon, cv. 'Vamont') maintained at a $3.2 \mathrm{~cm}$ height of cut.

In Florida, the experiment was conducted at the West Florida Research and Education Center (30.602534, -87.073204) on a 20+ year-old stand of 'TifSport' hybrid bermudagrass (Cynodon dactylon (L.) Pers. $\times$ Cynodon transvaalensis Burtt Davy) maintained as a golf course fairway at a $1.3 \mathrm{~cm}$ height of cut atop Fuquay loamy sand (loamy, kaolinitic, thermic Arenic Plinthic Kandiudults). Both experimental sites were naturally infested with ABG.

\subsubsection{Treatments and Experimental Design}

Experiments were arranged as randomized complete block designs of plots $(2.4 \times 6.1 \mathrm{~m})$ with four replications. At both sites, treatments included fraise mowing to a depth of 1.5 or $3.0 \mathrm{~cm}$. A non-treated check $(0 \mathrm{~cm})$ was included for comparison. Treatments were applied on 11 June 2019 in Tennessee and on 14 June 2019 in Florida using an Imants KORO Field Top Maker (KTM 1200, AQUA-AID Solutions, Rocky Mount, NC, USA) affixed to the power take-off assembly of a tractor.

Immediately following fraise mowing, the entirety of experimental sites, including the non-treated check, was treated with oxadiazon at $3.36 \mathrm{~kg} \mathrm{ha}^{-1}$ to prevent encroachment of summer annual weeds. In Tennessee, Ronstar Flo $\left(8.9 \mathrm{~L} \mathrm{ha}^{-1}\right.$, Bayer Environmental Science, Cary, NC, USA) was applied using a $\mathrm{CO}_{2}$-pressurized backpack sprayer calibrated to deliver $374 \mathrm{~L} \mathrm{ha}^{-1}$ via 8002 nozzles (TeeJet Technologies, Wheaton, IL, USA). In Florida, Ronstar G (167.8 kg ha ${ }^{-1}$, Bayer Environmental Science, Cary, NC, USA) was applied using a rotary spreader (Lesco, Cleveland, OH, USA).

\subsubsection{Bermudagrass Regrowth}

Following fraise mowing, bermudagrass regrowth was assessed every other week for nineteen weeks after treatment, using visual ratings of bermudagrass cover on a 0 (i.e., no bermudagrass cover) to $100 \%$ (i.e., area completely covered in bermudagrass) scale. 


\subsubsection{Annual Bluegrass Control}

Annual bluegrass control was determined monthly from January to April of the spring following fraise mowing. In Tennessee, ABG cover was quantified using two $1 \mathrm{~m}^{2}$ grids with 100 intersections in each experimental unit. Annual bluegrass was recorded as present or absent at each grid intersection. The number of intersections marked present was converted to a percentage and averaged within plots to determine annual bluegrass cover. In Florida, $\mathrm{ABG}$ control was assessed by averaging the number of individual ABG plants counted in two $0.5 \mathrm{~m}^{2}$ areas within each experimental unit.

\subsubsection{Statistical Analysis}

Due to differences in data collection between experimental locations, data from TN and FL were analyzed separately. Turfgrass cover data were subjected to non-linear regression in Prism (Prism 9 for Mac, GraphPad Software, La Jolla, CA, USA) to determine the number of days following fraise mowing required to achieve $50 \%, 75 \%$ and $95 \%$ regrowth. The 'ECanything' model was used to assess regrowth to each threshold with the equation

$$
\begin{gathered}
\mathrm{EC}(\%)=\mathrm{ECF} /(\mathrm{F} /(100-\mathrm{F}))^{\wedge}(1 / \text { HillSlope }) \\
\mathrm{Y}=\text { Bottom }+(\text { Top-Bottom }) /\left(1+(\mathrm{EC} \% / \mathrm{X})^{\wedge} \text { HillSlope }\right)
\end{gathered}
$$

where $\mathrm{F}$ is the desired percent regrowth and ECF is the number of days that gives a response of $\mathrm{F}$ between the Top and Bottom. Top and Bottom are plateaus in the units of the $\mathrm{Y}$ axis, constrained at 100 and 0, respectively. HillSlope describes the steepness of the family of curves and was constrained to 1.0.

Treatment means for ABG control data were separated using the mixed procedure in SAS (University Edition, Cary, NC) at $p \leq 0.05$ according to Fisher's protected Least Significant Difference test.

\subsection{Turfgrass Practitioner Perspectives \\ 2.2.1. Research Approach}

To determine potential barriers to the adoption of fraise mowing as a weed control strategy, a qualitative assessment of turfgrass managers' thoughts about and experiences with fraise mowing was conducted. Four study participants from each state were intentionally recruited to engage in individual interviews via the fraise mowing contracting company Aqua AID Solutions (Rocky Mount, NC, USA). Researchers sought to engage participants in Tennessee and Florida, states where quantitative data were collected, representing a diverse sample of managed turfgrass systems and backgrounds in using fraise mowing. A personal connection to a secondary researcher working for Aqua AID Solutions, provided a list of previous clients meeting these criteria who had contracted fraise mowing for their facilities in either Florida or Tennessee.

Five participants work as superintendents managing turfgrass on golf courses and three participants maintain turfgrass on athletic fields. Participants had a range of experience fraise mowing from only having fraise mown once to implementing the practice annually, including fraise mowing select areas such as tees only to areas as large as $12.1 \mathrm{ha}^{-1}$, and fraise mowing for renovation, thatch control, and weed control.

This research was approved by the University of Tennessee's Institutional Review Board prior to contacting participants (UTK IRB-21-06256-XP; 11 March 2021). All participants received a letter describing potential risks and benefits of participation prior to being interviewed. Voluntary participation after reviewing potential risks was considered consent. To protect all parties participating in this study, the identity of interviewees and their affiliated workplaces remains confidential.

\subsubsection{Data Collection}

Data were obtained by conducting semi-structured interviews remotely via the video conference platform Zoom (Zoom Video Communications Inc., San Jose, CA, USA). One 
primary researcher conducted interviews by asking four non-leading questions: "What is your familiarity with fraise mowing?", "Do you implement fraise mowing at your facility? If so, why, and what factors influenced your decision to fraise mow?", "Do you feel there are barriers or challenges to adopting fraise mowing as a weed control measure?", and "What are your thoughts on fraise mowing related to weed control?". Participants were encouraged to share their thoughts in a conversational manner and to provide additional information beyond the posed research questions. Each interview lasted approximately $15 \mathrm{~min}$ and was recorded. During interviews, the primary researcher documented descriptive and reflective notes.

\subsubsection{Data Analysis}

Interviews were transcribed by Rev transcription company (Rev, Austin, TX, USA) and analyzed with the primary researcher's notes to create themes. Themes were developed by examining data for significant statements and elements of meaning, creating textural and structural descriptions, and recognizing descriptions revealing commonalities among participant responses [43]. Themes were then open-coded to determine the main concepts. To validate themes, two secondary researchers analyzed and coded themes in addition to the primary researcher. All three researchers then discussed their coding and agreed upon themes and concepts.

To mitigate researcher bias, the credibility of the study was achieved through triangulation of data sources, methods, and investigators [43], and by conducting member checks of data interpretation and conclusions. Study dependability was gained through peer review by a researcher trained in qualitative analysis.

\section{Results}

\subsection{Bermudagrass Regrowth}

In both locations, bermudagrass regrowth was swiftest at the shallower fraise mowing depth of $1.5 \mathrm{~cm}$ (Figure 3). At the $1.5 \mathrm{~cm}$ depth, bermudagrass regrowth occurred more quickly and reached full recovery faster in Florida than in Tennessee. However, bermudagrass regrowth when fraise mown to a $3.0 \mathrm{~cm}$ depth was similar between locations.

In Tennessee, bermudagrass reached $50 \%$ recovery 39 days after fraise mowing to a $1.5 \mathrm{~cm}$ depth and took 98 days to fully recover from that application. Comparatively, at the $3.0 \mathrm{~cm}$ depth, $50 \%$ regrowth was not achieved until 59 days after fraise mowing and bermudagrass required 119 days to reach fully recovery.

In Florida, bermudagrass fraise mown to $1.5 \mathrm{~cm}$ was $50 \%$ recovered 22 days after treatment and was fully recovered after 52 days. Bermudagrass fraise mown to a depth of $3.0 \mathrm{~cm}$ reached $50 \%$ recovery 53 days after treatment and required 106 days for full recovery.

\subsection{Annual Bluegrass Control}

Fraise mowing at both depths reduced ABG populations the following spring compared to the non-treated check in both study locations (Tables 1 and 2). No differences in ABG control between fraise mowing depths were observed on any rating date in either study location.

In Tennessee, fraise mowing at either depth resulted in effective ABG control throughout the spring (93-97\%). Comparatively, ABG control in Florida ranged from 41-78\%. Peak ABG control in Florida was observed in January and declined thereafter. Interestingly, the number of $A B G$ plants in the non-treated check plots decreased over time, eventually reaching 0 by April. 

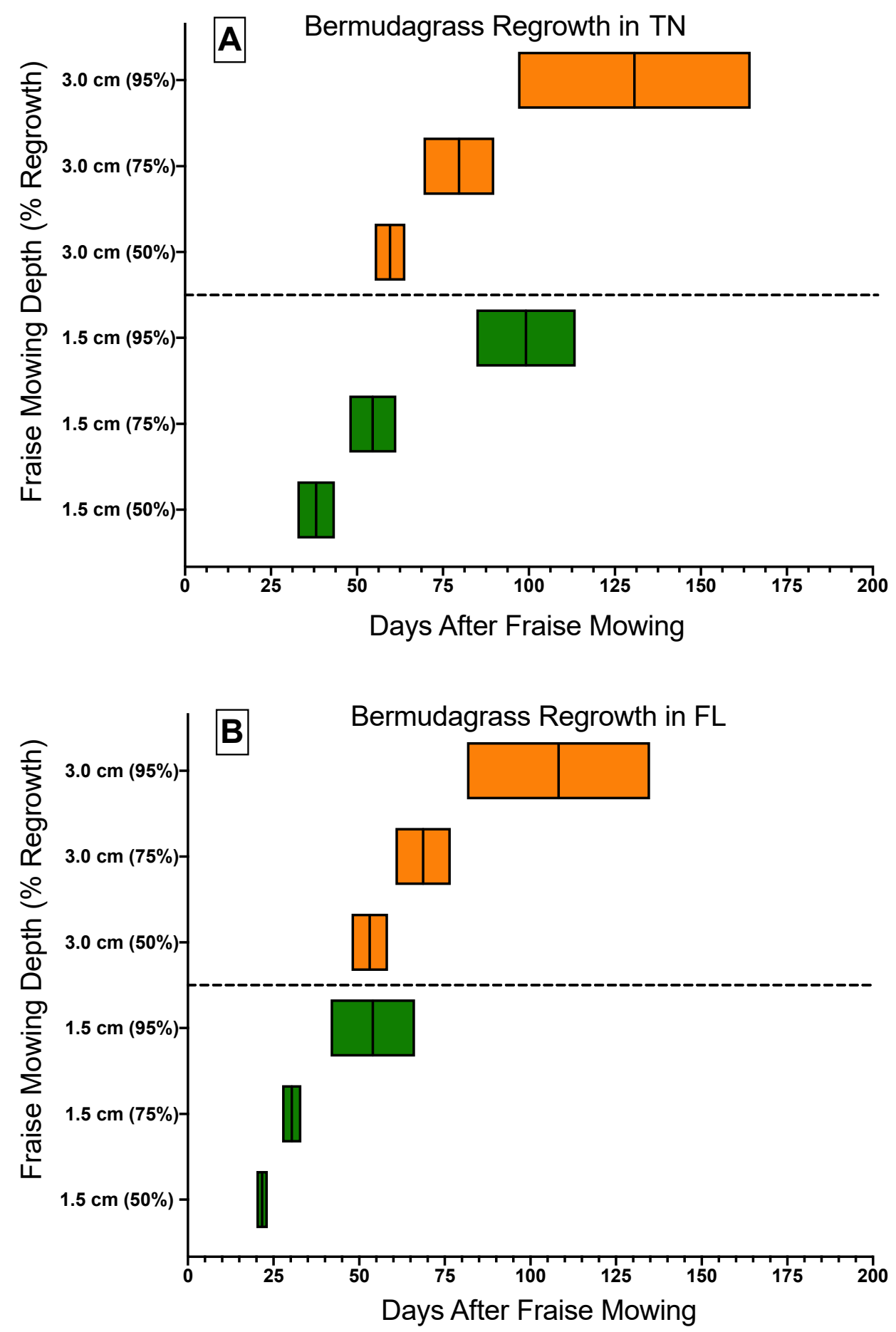

Figure 3. Regrowth of $\mathrm{A}=$ Common bermudagrass (Cynodon dactylon, cv. 'Vamont') in Knoxville, $\mathrm{TN}$ and $\mathrm{B}=$ 'TifSport' hybrid bermudagrass (Cynodon dactylon (L.) Pers. $\times$ Cynodon transvaalensis Burtt Davy) in Jay, FL following fraise mowing applications in June 2019. Green and orange boxes represent regrowth following fraise mowing at 1.5 and $3.0 \mathrm{~cm}$ depths, respectively. The center line of each box indicates days to percent regrowth benchmarks of 50,75, or $95 \%$ with $95 \%$ confidence intervals indicated by lines on either side of the mean. 
Table 1. Percentage of annual bluegrass (Poa annua L.) in common bermudagrass (Cynodon dactylon, cv. 'Vamont') maintained at a $3.2 \mathrm{~cm}$ height of cut following fraise mowing applications in June 2019 in Knoxville, TN.

\begin{tabular}{ccccc}
\hline & \multicolumn{4}{c}{ Percent Annual Bluegrass $^{\mathbf{z}}$} \\
\cline { 2 - 5 } Treatment & January & February & March & April \\
\hline Non-treated check & $33 \mathrm{a}^{\mathrm{x}}$ & $38 \mathrm{a}$ & $56 \mathrm{a}$ & $62 \mathrm{a}$ \\
Fraise mow $1.5 \mathrm{~cm}$ & $0 \mathrm{~b}$ & $1 \mathrm{~b}$ & $2 \mathrm{~b}$ & $2 \mathrm{~b}$ \\
Fraise mow $3.0 \mathrm{~cm}$ & $1 \mathrm{~b}$ & $2 \mathrm{~b}$ & $4 \mathrm{~b}$ & $2 \mathrm{~b}$ \\
\hline
\end{tabular}

${ }_{\mathrm{z}}$ Percentage of annual bluegrass was determined using a $1 \mathrm{~m}^{2}$ grid with 100 intersections. Annual bluegrass was recorded as present or absent at each intersect. Two grid counts were taken per experimental unit on each rating date. ${ }^{y}$ Fraise mowing was performed on 11 June 2019. ${ }^{\mathrm{x}}$ Means in a column followed by the same letter are not significantly different at $p \leq 0.05$, according to Fisher's Protected Least Significant Difference test.

Table 2. Annual bluegrass (Poa annua L.) plants in 'TifSport' hybrid bermudagrass (Cynodon dactylon (L.) Pers. $\times$ Cynodon transvaalensis Burtt Davy) maintained as a golf course fairway following fraise mowing applications in June 2019 in Jay, FL.

\begin{tabular}{ccccc}
\hline & \multicolumn{4}{c}{ Annual Bluegrass Plants ${ }^{\mathbf{z}}$} \\
\cline { 2 - 5 } Treatment $\mathbf{y}$ & January & February & March & April \\
\hline Non-treated check & $74 \mathrm{a}^{\mathrm{x}}$ & $59 \mathrm{a}$ & $26 \mathrm{a}$ & 0 \\
Fraise mow $1.5 \mathrm{~cm}$ & $19 \mathrm{~b}$ & $42 \mathrm{a}$ & $11 \mathrm{~b}$ & 0 \\
Fraise mow $3.0 \mathrm{~cm}$ & $16 \mathrm{~b}$ & $35 \mathrm{a}$ & $9 \mathrm{~b}$ & 0 \\
\hline
\end{tabular}

${ }^{\mathrm{z}}$ Annual bluegrass plant number was determined by counting the number of plants in two $0.5 \mathrm{~m}^{2}$ areas within each experimental unit and calculating the average. ${ }^{y}$ Fraise mowing was performed on 17 June 2019. ${ }^{x}$ Means in a column followed by the same letter are not significantly different at $p \leq 0.05$, according to Fisher's Protected Least Significant Difference test.

\subsection{Turfgrass Practitioner Perspectives}

Participants described similar positive and negative aspects of fraise mowing for a variety of uses. No differences in responses were revealed between turfgrass managers in Tennessee and turfgrass managers in Florida; therefore, data were combined for theme development. Two main themes were discovered, which encompassed the responses of all participants: benefits and challenges.

\subsubsection{Benefits}

Fraise mowing was described as a useful management tool for a variety of reasons including drainage improvement; removal of thatch, sand dams (i.e., raised areas that impede surface drainage), or other unwanted material; surface leveling; and weed control. All participants indicated that they were satisfied with the results of fraise mowing implemented at their facility. Participants managing golf courses only used fraise mowing to improve the quality of driving-range tees. However, they noted that fraise mowing would also be beneficial on putting-green collars, par-three tee boxes, or other high-traffic areas. Participants managing athletic fields fraise mowed on much larger scales, as the entirety of a field was commonly fraise mown at a single time.

Many participants considered fraise mowing a less expensive alternative to other renovation methods and explained that fraise mowing provided multiple benefits to their facilities. Labor costs were reported to be lower for fraise mowing when compared to complete renovation. Additionally, some turfgrass managers indicated fraise mowing increased labor availability as athletic fields were closed following fraise mowing, allowing them to direct labor inputs elsewhere. Debris generated from fraise mowing was also considered cost-effective as many turfgrass managers used harvested material as planting stock to renovate other areas of their turfgrass systems. These added benefits of fraise mowing were considered advantageous.

Weed control was also discussed as a benefit of fraise mowing. For example, while seven out of the eight participants did not implement fraise mowing specifically for weed 
control, all seven participants who used fraise mowing for other reasons observed significant reductions in ABG, goosegrass (Eleusine indica L.), crabgrass (Digitaria spp.), dallisgrass (Paspalum dilatatum Poir), or broadleaf weed populations. Additionally, when fraise mowing was implemented in turfgrass stands overseeded with perennial ryegrass, turfgrass managers removed perennial ryegrass without the use of herbicide while also removing organic matter and improving drainage.

For these reasons, one of the study participants has implemented fraise mowing specifically as a weed-management practice. This turfgrass manager reported over a $50 \%$ reduction in herbicide use since adding fraise mowing as a regular component of his management plan. Other practitioners not using fraise mowing explicitly for weed management agreed that herbicide inputs could likely be reduced via fraise mowing.

Therefore, fraise mowing was described as a sustainable turfgrass management tool. Multiple study participants expressed that in addition to reducing herbicide use, other pesticide or fertilizer inputs may be reduced by fraise mowing, as the practice promotes overall turfgrass health. Participants speculated weed control observed after fraise mowing was due to physical removal of weed seed in addition to improved turfgrass health. Healthy turfgrass was noted to prevent weeds and require fewer synthetic inputs.

\subsubsection{Challenges}

Although fraise mowing was considered a positive cultural practice with many benefits, all interviewed participants described challenges associated with implementation. Barriers to use included cost, labor, debris removal, space closure, and the need for communication with membership.

The cost of fraise mowing was the most prohibitive challenge to its adoption. All eight participants from facilities with a wide range of use and budgets indicated cost was the limiting factor in their decision to fraise mow. Although less expensive than other renovation tools, both the purchasing of a fraise mowing unit and the contracting of thirdparty companies were noted to be expensive. Therefore, turfgrass managers were highly selective as to which areas to fraise mow and, generally, felt they could not afford to fraise mow purely for weed control.

The cost of tools and labor involved in fraise mowing and removing debris afterward were also cited as limitations to implementation. One turfgrass manager summarized the time and labor involved in fraise mowing by saying, "I always joke around that it took us two hours to complete the project, but it took us two days to clean up the mess that it created." Another participant described the need for multiple trailers in order to dispose of material efficiently. He believed this was an added cost to the practice, as a facility would either need to purchase more trailers or spend money on additional labor to clean debris effectively.

Where to relocate debris also presented a challenge for some participants. Participants in this study either had access to dump piles, gave away debris, or used debris to renovate other areas. Participants believed if these options were not practical, the need for dumpsters would be a high additional cost. In terms of fraise mowing for weed control, using debris elsewhere was discussed as an issue because removed weed seed would be transported and established in other locations at the facility, which would defeat the purpose of fraise mowing as a weed control tool.

A universal challenge to all study participants was the inability to use fraise-mown areas during the turfgrass regrowth period. Turfgrass managers typically closed athletic fields or tee boxes for approximately four weeks while turfgrass recovered. To combat this issue, turfgrass managers sought to implement fraise mowing when their facility was closed (i.e., college athletic fields in summer when teams do not play) or used infrequently (i.e., in mid-July in Florida, golf play is limited due to heat). In some situations, fraise mown areas were immediately needed for use, causing turfgrass managers to only fraise mow half the area at a time or to place driving range mats in front of tee boxes to keep a driving range open. 
All of the aforementioned challenges influenced turfgrass manager decision-making to fraise mow every few years rather than annually, and to only fraise mow small areas such as the practice tee rather than large acreages such as fairways. Many turfgrass managers expressed their desire to fraise mow larger areas or to implement the practice for weed control, but felt their budgets, labor availability, or stakeholder needs prevented their ability to do so. For these reasons, many participants discussed the importance of communicating the benefits and challenges of fraise mowing to members and stakeholders. Turfgrass managers believed some issues in acquiring funding or closing areas could be mitigated by explaining long-term benefits to those using the space.

\section{Discussion}

Fraise mowing is an effective non-chemical means of controlling ABG in bermudagrass. Across locations and depths in this experiment, ABG control ranged from $48-97 \%$. This level of control is far greater than the $24 \%$ ABG reduction previously observed in zoysiagrass [21] and is similar to the near 100\% control of ABG in perennial ryegrass [40].

In Tennessee, fraise mowing was highly effective in controlling ABG from January to April. ABG control in Florida was lower than in Tennessee; fraise mowing did not significantly reduce ABG in February or April. This response may be due to increased air temperatures in FL, contributing to natural senescence of $A B G$ following an annual life-cycle as spring temperatures warm (Figure 4).

Variable ABG control between locations also indicates fraise mowing efficacy differs when implemented in various turfgrass species. ABG control when fraise mowing hybrid bermudagrass in Florida was lower than that observed after fraise mowing common bermudagrass in Tennessee. Although the same turfgrass genus, differences in turfgrass growth, vigor, and thatch production between common and hybrid bermudagrass likely influenced ABG control in this study.

For similar reasons, bermudagrass regrowth may have been enhanced in Florida. Bermudagrass fully recovered much more quickly in Florida than in Tennessee, especially at the $1.5 \mathrm{~cm}$ fraise mowing depth. Differences in turfgrass variety, supplemental irrigation, mowing height and frequency, and growing conditions likely encouraged swifter regrowth at the Florida study site, which was more intensively managed as a golf course fairway in a warmer climate with more rainfall than the Tennessee site maintained as utility turfgrass (Figure 4).

In both locations, bermudagrass regrowth was swiftest at the shallow $(1.5 \mathrm{~cm})$ fraise mowing depth. This finding is not surprising as more stolons, rhizomes, and plant tissue remained at this depth compared to the deep $(3.0 \mathrm{~cm})$ treatment. The length of time required for recovery, 52 or 98 days in Florida versus Tennessee, at $1.5 \mathrm{~cm}$ is comparable to the hybrid bermudagrass regrowth period observed by McCauley et al. [41]. They reported hybrid bermudagrass fraise mown at $0.6,1.3$, and $1.9 \mathrm{~cm}$ required approximately 28 to 42 days to recover. In this study, hybrid bermudagrass in Florida recovered in a similar time frame, while common bermudagrass in Tennessee took longer to re-establish.

Considering these climatic and management factors is important for turfgrass managers implementing fraise mowing, as they will likely affect the length of time required for regrowth, thus dictating the amount of time fraise-mown areas will be closed for use. Given that no ABG control differences were observed between fraise mowing depths in this experiment, the shallower depth is recommended in order to enhance regrowth and mitigate closure time while still effectively controlling ABG. 

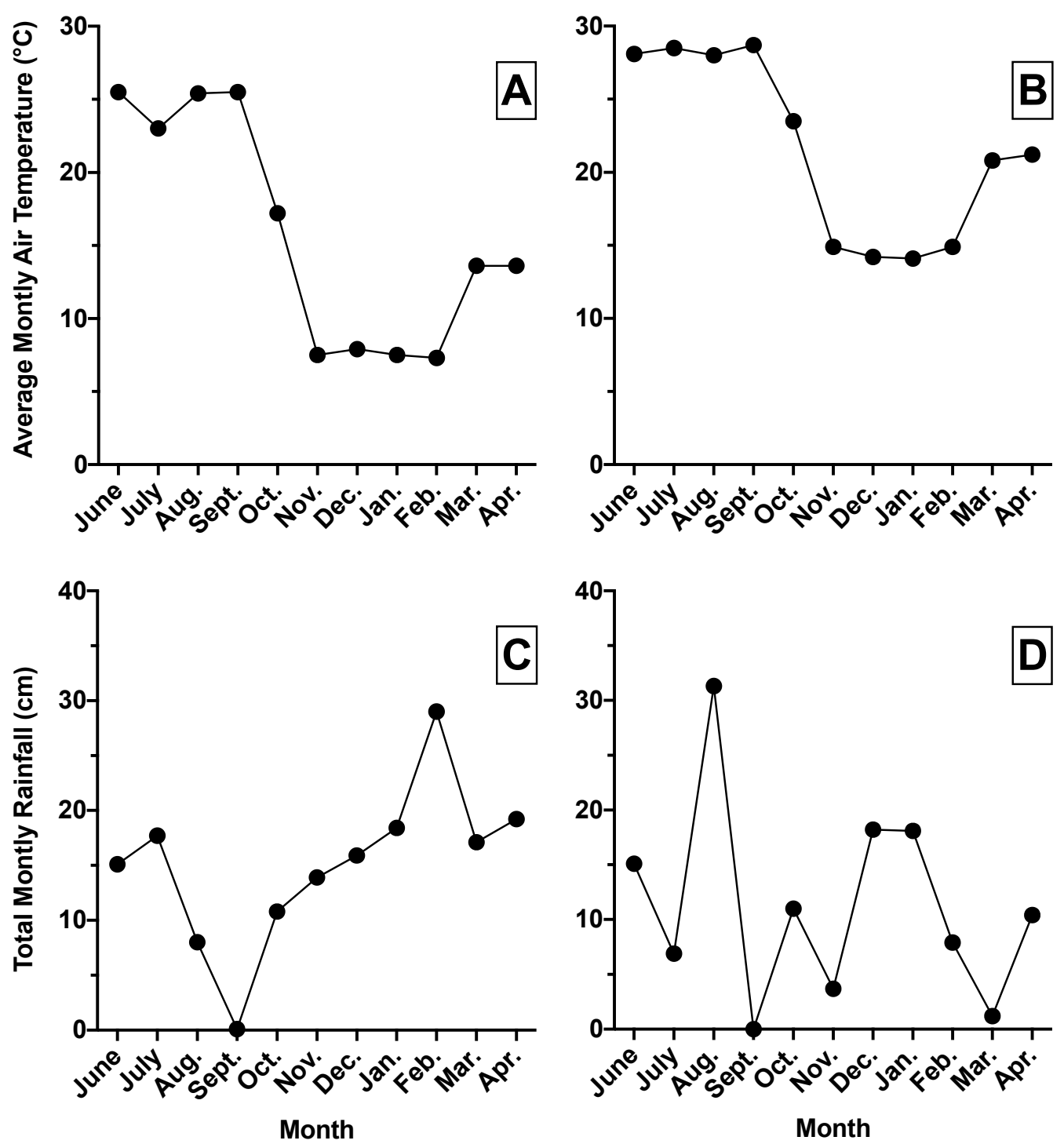

Figure 4. Average monthly air temperature and total monthly rainfall in Knoxville, TN and Jay, FL from June 2019 to April 2020 where $\mathrm{A}=$ average monthly air temperature in Knoxville, TN; B = average monthly air temperature in Jay, FL; C = total monthly rainfall in Knoxville, TN; and D = total monthly rainfall in Jay, FL.

Results from this research demonstrate fraise mowing is a sustainable weed-management practice, however decision-making regarding implementation was influenced by economic and social barriers. Turfgrass managers discussed that while they believed fraise mowing was an effective and environmentally friendly tool for weed control compared to synthetic herbicides, they were generally unwilling to implement the practice due to cost, even if herbicide resistance was highly problematic. This response parallels barriers limiting adoption of herbicide resistance management strategies in agronomic cropping systems [31]. In that work, authors revealed that farmers tended to focus on immediate economic returns rather than long-term effects of herbicide resistance. Additionally, social barriers, including ideas that herbicide resistance is unavoidable due to the actions of others and that new chemistries will continue to be produced, negatively impacted the likelihood of farmers using herbicide resistance mitigation practices.

Given that ABG is rapidly becoming resistant to herbicides from multiple mode of action groups [11], these barriers to adoption of alternative control measures must be overcome. Turfgrass mangers should be encouraged to consider the long-term economic effects of development of herbicide resistant ABG populations at their facility. Although fraise mowing can be considered expensive when assessed as a singular event, the removal 
of herbicide-resistant weed seed may save money on chemical products required for control if resistance progresses and ultimately reduce the number of herbicide applications required for control. To reduce the costs of fraise mowing, turfgrass managers can scout and map their facilities to identify small areas that are particularly infested with ABG or showing signs of potential resistance. Fraise mowing these small areas will be less expensive and more effective than using the practice on large acreages.

The responses of turfgrass managers interviewed in this study demonstrate that there is a need to provide additional education on herbicide resistance and alternative options to traditional chemical weed control. Fraise mowing is a viable mechanical control option that concurrently promotes healthier turfgrass. Turfgrass managers must weigh the value of fraise mowing against the challenges of implementation. Sustainable, non-chemical weed control measures such as fraise mowing may become necessary as herbicide resistance issues increase. These measures may also become essential as herbicide use is limited or banned in some areas due to the increasingly negative public perception of herbicides and legislated restrictions [44,45].

Given the social and economic importance of turfgrass and the growing issue of herbicide resistance, deeper study of fraise mowing as a weed control tool and investigation of other sustainable weed management practices are needed. Future work should compare the efficacy of fraise mowing across a range of bermudagrass cultivars varying in vigor. In this study, fraise mowing efficacy for $\mathrm{ABG}$ control was lower on the more aggressive growing 'TifSport 'hybrid bermudagrass variety than 'Vamont' common bermudagrass. New selections bred for optimal traffic tolerance may recover more quickly than those assessed here. Considering a wide range of bermudagrass cultivars are managed in the turfgrass industry, this information would be valuable to turfgrass managers considering fraise mowing.

Additionally, assessment of fraise mowing efficacy on ABG at depths $\leq 1.5 \mathrm{~cm}$ is warranted. Shallower fraise mowing depths will likely result in swifter bermudagrass regrowth and generate less debris. Furthermore, determining methods to clean debris by either removing or destroying weed seed is needed. In grain crops, tools such as the Harrington Seed Destructor have been developed to devitalize seeds from chaff during harvest [46]. If fraise mowing debris can be freed of weed seed, turfgrass managers can use material to establish or renovate other areas of their facilities, thus making fraise mowing more affordable and more likely to be implemented. A cost analysis of fraise mowing compared to other weed control strategies would be valuable and is a needed area of future exploration.

Understanding such barriers to the adoption of fraise mowing would not have been possible without qualitative examination of practitioner perspectives. There is a need for future turfgrass research of any kind to determine and address factors influencing practitioners' abilities and decisions to implement research findings using methods beyond speculation. Such investigation is necessary to the promotion of sustainable turfgrass management.

Author Contributions: Conceptualization, J.T.B. and J.B.U.; Data curation, D.E.C., C.M. and P.A.B.; Formal analysis, D.E.C.; Funding acquisition, J.T.B. and J.B.U.; Investigation, D.E.C., C.M. and P.A.B.; Methodology, J.T.B., J.B.U. and C.A.S.; Project administration, D.E.C., J.T.B., C.M. and P.A.B.; Supervision, C.A.S.; Validation, J.T.B. and C.A.S.; Writing-original draft, D.E.C.; Writing-review and editing, J.T.B., J.B.U., C.A.S., C.M. and P.A.B. All authors have read and agreed to the published version of the manuscript.

Funding: This research was funded as part of a regional collaborative project supported by the USDANIFA, Award No. 2018-51181-28436, "Research and Extension to Address Herbicide Resistance Epidemic in Annual Bluegrass in Managed Turf Systems".

Institutional Review Board Statement: The study was conducted according to the guidelines of the Declaration of Helsinki and approved by the Institutional Review Board of The University of Tennessee (protocol code UTK IRB-21-06256-XP, approved on 11 March 2021). 
Informed Consent Statement: Written subject consent was waived due to the limited risk of participation and participant anonymity. Willingness of the subject to participate after being provided a consent document outlining risks and benefits of participation constituted documentation of consent.

Data Availability Statement: The dataset used in this paper was derived from field research experiments conducted by Pablo Boeri, James Brosnan, Devon Carroll, Chase McKeithen, and J. Bryan Unruh as part of the SCRI-POA project. Research data and supporting metadata are stored in the team's centralized database. Project Website: www.resistpoa.org.

Acknowledgments: Authors thank the City of Knoxville Parks and Recreation Department and the turfgrass research support staff at the University of Tennessee and the University of Florida for their assistance in conducting this research.

Conflicts of Interest: The authors declare no conflict of interest. The funders had no role in the design of the study; in the collection, analyses, or interpretation of data; in the writing of the manuscript, or in the decision to publish the results.

\section{References}

1. Milesi, C.; Running, S.W.; Elvidge, C.D.; Dietz, J.B.; Tuttle, B.T.; Nemani, R.R. Mapping and modeling the biogeochemical cycling of turf grasses in the United States. Environ. Manag. 2005, 36, 426-438. [CrossRef]

2. United States Department of Agriculture. Crop Acreage Data 31 July 2020. 2020. Available online: https://www.fsa.usda.gov/ news-room/efoia/electronic-reading-room/frequently-requested-information/crop-acreage-data/index (accessed on 27 April 2020).

3. Haydu, J.J.; Hodges, A.W.; Hall, C.R. Economic Impacts of the Turfgrass and Lawncare Industry in the United States; FE632; University of Florida Institute of Food and Agricultural Sciences Extension: Gainesville, FL, USA, 2006; pp. 1-39.

4. Stackhouse, T.; Martinez-Espinoza, A.D.; Emran Ali, M. Turfgrass disease diagnosis: Past, present, and future. Plants 2020, 9 , 1544. [CrossRef]

5. Soldat, D.J.; Brosnan, J.T.; Chandra, A.; Gaussoin, R.E.; Kowalewski, A.; Leinauer, B.; Rossi, F.S.; Stier, J.C.; Unruh, J.B. Estimating economic minimums of mowing, fertilizing, and irrigating turfgrass. Agric. Environ. Lett. 2020, e20032. [CrossRef]

6. Brosnan, J.T.; Chandra, A.; Gaussoin, R.E.; Kowalewski, A.; Leinauer, B.; Rossi, F.S.; Soldat, D.J.; Stier, J.C.; Unruh, J.B. A justification for continued management of turfgrass during economic contraction. Agric. Environ. Lett. 2020, e20033. [CrossRef]

7. Amani-Beni, M.; Zhang, B.; Xie, G.-D.; Xu, J. Impact of urban park's tree, grass, and waterbody on microclimate in hot summer days: A case study of Olympic Park in Beijing, China. Urban For. Urban Green 2018, 32, 1-6. [CrossRef]

8. Braun, R.C.; Bremer, D.J. Carbon sequestration in zoysiagrass turf under different irrigation and fertilization management regimes. Agrosyst. Geosci. Environ. 2019, 2, 180060. [CrossRef]

9. Tanner, R.A.; Gange, A.C. Effects of golf courses on local biodiversity. Landsc. Urban Plan. 2005, 71, 137-146. [CrossRef]

10. Nicholls, S.; Crompton, J.L. The impact of a golf course on residential property values. J. Sport Manag. 2007, 21, 555-570. [CrossRef]

11. Brosnan, J.T.; Elmore, M.T.; Bagavathiannan, M.V. Herbicide-resistant weeds in turfgrass: Current status and emerging threats. Weed Technol. 2020, 34, 424-430. [CrossRef]

12. Gadermaier, G.; Dedic, A.; Obermeyer, G.; Frank, S.; Himly, M.; Ferreira, F. Biology of weed pollen allergens. Curr. Allergy Asthma Rep. 2004, 4, 391-400. [CrossRef]

13. Larsen, J.L.; Kesheimer, A.J.; Potter, D.A. Pollinator assemblages on dandelions and white clover in urban and suburban lawns. J. Insect Conserv. 2014, 18, 863-873. [CrossRef]

14. Stewart-Wade, S.M.; Neumann, S.; Collins, L.L.; Boland, G.J. The biology of Canadian weeds. 177. Taraxacum officinale G.H. Weber ex Wiggers. Can. J. Plant Sci. 2002, 82, 825-853.

15. Brosnan, J.T.; Dickson, K.H.; Sorochan, J.C.; Thoms, A.W.; Stier, J.C. Large crabgrass, white clover, and hybrid bermudagrass athletic field playing quality in response to simulated traffic. Crop Sci. 2014, 54, 1838-1843. [CrossRef]

16. Rana, S.S.; Askew, S.D. Measuring canopy anamoly influence on golf putt kinematics: Does annual bluegrass influence bal roll behavior? Crop Sci. 2018, 58, 911-916. [CrossRef]

17. Van Wychen, L. 2020 Survey of the Most Common and Troublesome Weeds in Grass Crops, Pasture and Turf in the United States and Canada. Weed Science Society of America National Weed Survey Dataset 2020. Available online: https://wssa.net/wssa/ weed/surveys/ (accessed on 27 April 2020).

18. Smiley, R.W.; Dernoeden, P.H.; Clarke, B.B. Compendium of Turfgrass Diseases, 3rd ed.; The American Phytopathological Society: Saint Paul, MN, USA, 2005.

19. Inguagiato, J.C.; Martin, S.B. Disease of Cool- and Warm-Season Putting Greens; United States Golf Association Green Section Record: Liberty Corner, NJ, USA, 2015; Volume 53.

20. Beard, J.B.; Olien, C.R. Low temperature injury in the lower portion of Poa annua L. crowns. Crop Sci. 1963, 3, 362-363. [CrossRef]

21. Brosnan, J.T.; Breeden, G.K.; Zobel, J.M.; Patton, A.J.; Law, Q.D. Nonchemical annual bluegrass (Poa annua) management in zoysiagrass via fraise mowing. Weed Technol. 2020, 34, 482-488. [CrossRef] 
22. Ghanizadeh, H.; Mesarich, C.H.; Harrington, K.C. Molecular characteristics of the first case of haloxyfop-resistant Poa annua. Sci. Rep. 2020, 10, 4231. [CrossRef]

23. Cross, R.B.; McCarty, L.B.; Tharayil, N.; Whitwell, T.; Bridges, W.C. Detecting annual bluegrass (Poa annua) resistance to ALS-inhibiting herbicides using a rapid diagnostic assay. Weed Sci. 2013, 61, 384-389. [CrossRef]

24. McElroy, J.S.; Flessner, M.L.; Wang, Z.; Dane, F.; Walker, R.H.; Wehtje, G.R. A Trp574 to Leu amino acid substitution in the ALS gene of annual bluegrass (Poa annua) is associated with resistance to ALS-inhibiting herbicides. Weed Sci. 2013, 61, 21-25. [CrossRef]

25. Lowe, D.B.; Swire-Clark, G.A.; McCarty, L.B.; Whitwell, T.; Baird, W.V. Biology and molecular analysis of dinitroaniline-resistant Poa annua L. Int. Turfgrass Soc. Res. J. 2001, 9, 1019-1025.

26. Kelly, S.T.; Coats, G.E.; Luthe, D.S. Mode of resistance of triazine resistant annual bluegrass (Poa annua). Weed Technol. 1999, 13, 747-752. [CrossRef]

27. Binkholder, K.N.; Fresenburg, B.S.; Teuton, T.C.; Xiong, X.; Smeda, R.J. Selection of glyphosate-resistant annual bluegrass (Poa annua L.) on a golf course. Weed Sci. 2011, 59, 286-289. [CrossRef]

28. Brosnan, J.T.; Vargas, J.J.; Spesard, B.; Netzband, D.; Zobel, J.M.; Chen, J.; Patterson, E.L. Annual bluegrass (Poa annua) resistance to indaziflam applied early-postemergence. Pest Manag. Sci. 2020, 76, 2049-2057. [CrossRef]

29. Heap, I. The International Herbicide-Resistant Weed Database 2021. Available online: http:/ / weedscience.org/Pages/Species. aspx (accessed on 16 March 2021).

30. Brosnan, J.T.; Vargas, J.J.; Breeden, G.K.; Zobel, J.M. Herbicide resistance in annual bluegrass on Tennessee golf courses. Crop Forage Turfgrass Manag. 2020, 6, e20050. [CrossRef]

31. Norsworthy, J.K.; Ward, S.M.; Shaw, D.R.; Llewellyn, R.S.; Nichols, R.L.; Webster, T.M.; Bradley, K.W.; Frisvold, G.; Powles, S.B.; Burgos, N.R.; et al. Reducing the risks of herbicide resistance: Best management practices and recommendations. Weed Sci. 2012, 60, 31-62. [CrossRef]

32. Watschke, T.L.; Long, F.W.; Duich, J.M. Control of Poa annua by suppression of seedheads with growth regulators. Weed Sci. 1979, 27, 224-231. [CrossRef]

33. Lush, M. Biology of Poa annua in a temperate zone golf putting green (Agrostis stolonifera/Poa annua). II. The Seed Bank. J. Appl. Ecol. 1988, 25, 989-997. [CrossRef]

34. Gaussoin, R.E.; Branham, B.E. Influence of cultural factors on species dominance in a mixed stand of annual bluegrass/creeping bentgrass. Crop Sci. 1989, 29, 480-484. [CrossRef]

35. Bearss, R.C.; Rogers, N.J.; Crum, J.R.; Silcox, C.A. Fairway renovation with fraise mowing cultivation and dazoment fumigation. HortScience 2020, 55, 122-1227. [CrossRef]

36. Miller, G.L.; Earlywine, D.T.; Fresenburg, B.S. Effect of fraze mowing on spring dead caused by Ophiosphaerella hepotricha of bermudagrass. Int. Turfgrass Soc. Res. J. 2017, 13, 225-228. [CrossRef]

37. Richardson, M.D.; Brosnan, J.T.; McCalla, J.H.; Breeden, G.K. Fraise mowing can improve herbicidal control of bermudagrass. Int. Turfgrass Soc. Res. J. 2020. [CrossRef]

38. Munshaw, G.C.; Dickson, K.H.; Cropper, K.L.; Sorochan, J.C. The effect of fraze mowing an overseed establishment in Cynodon dactylon turf. Int. Turfgrass Soc. Res. J. 2017, 13, 380-382. [CrossRef]

39. Dickson, K.H.; Segars, C.A.; Sorochan, J.C.; Moss, J.Q.; Harris, D.; Strunk, W.D. Comparison of mechanical removal of perennial ryegrass overseeding out of bermudagrass to chemical transitions. Int. Turfgrass Soc. Res. J. 2020. [CrossRef]

40. Baker, S.W.; Owen, A.G.; Woollacott, A.R. Physical and chemical control of Poa annua on professional football pitches. J. Turfgrass Sport Surf. Sci. 2005, 81, 47-61.

41. McCauley, R.K.; Pinnix, G.D.; Miller, G.L. Fraise mowing as a spring transition aid. Crop Forage Turfgrass Manag. 2019, 5, 190025 [CrossRef]

42. Lyman, G.T.; Throssell, C.S.; Johnson, M.E.; Stacey, G.A.; Brown, C.D. Golf course profile describes turfgrass, landscape, and environmental stewardship features. Appl. Turfgrass Sci. 2007, 4, 1-25. [CrossRef]

43. Taylor, S.; Bogdan, R.; DeVault, M. Introduction to Qualitative Research, 4th ed.; John Wiley \& Sons: Hoboken, NJ, USA, 2015.

44. Dykstra, M.; Slute, B.; Wickens, A. Pesticide ban impacts: Three municipalities provide perspective. Sports Turfgrass Manag. 2010, 23, 20-24.

45. Non-Essential Pesticide Prohibitions, Cosmetic Pesticide Use Restriction Bill; County Council for Montgomery County: Rockville, Maryland, 2019; pp. 52-14.

46. Walsh, M.J.; Harrington, R.B.; Powles, S.B. Harrington seed destructor: A new nonchemical weed control tool for global grain crops. Crop Sci. 2012, 52, 1343-1347. [CrossRef] 